\title{
UROLITHIASIS IN PATIENTS WITH SPINAL CORD INJURY
}

\author{
By B. Nikakhtar, M.D., N. D. Vaziri, M.D., F. Khonsari, M.D., S. Gordon, M.D. \\ and M. D. Mirahmadi, M.D. \\ Spinal Cord Injury and Nephrology Sections, Long Beach V.A. Medical Center and Division \\ of Nephrology, University of California, Irvine, CA 927I7, U.S.A.
}

\begin{abstract}
The composition of the stone was determined in 24 paraplegic patients from whom 26 stones were surgically removed. Twenty-five of the 26 stones consisted of 90 per cent magnesium ammonium phosphate and Io per cent carbonate apatite. The remaining single stone was composed of 90 per cent calcium oxalate and Io per cent magnesium ammonium phosphate. Renal function improved significantly with the removal of the stones.
\end{abstract}

Key words: Spinal cord injury; Urolithiasis.

\section{Introduction}

UROLITHIASIS is a well-known complication of spinal cord injury (SCI). This has been generally attributed to the associated hypercalciuria (Freeman, I949), intractable urinary tract infection (Burr, I972), and impaired urine flow due to neuropathic bladder dysfunction. The great majority of the stones in these patients are primarily composed of calcium oxalate or magnesium ammonium phosphate with the latter being by far the most common. Urinary tract infection with ureaseproducing organisms results in marked elevation of urine $\mathrm{pH}$ and ammonium, thereby facilitating the formation of magnesium, ammonium, phosphate stone. By causing further obstruction and harbouring infections urinary stones compound the pre-existing renal and urinary tract complication of the SCI. Here we report our findings in 24 patients with spinal cord injury and urolithiasis.

\section{Patients and Methods}

Twenty-four paraplegic men, 32 to $7 \mathrm{I}$ years of age (50 \pm I I) were included in the study. The aetiology of the spinal cord lesion included: compression fracture of the spine, spinal cord tumours and gunshot injury. The anatomical distribution of the spinal cord injury in our patients is displayed in Table I. All patients had exhibited urolithiasis requiring surgical intervention, the diagnosis of urolithiasis being established by intravenous urography, plain abdominal roentgenography, and/or abdominal ultrasonography. Chemical analysis was utilised to determine the composition of the stones. Relevant clinical and laboratory data were obtained from the patients' medical records.

\section{Results}

The duration between the onset of spinal cord injury and the diagnosis of urolithiasis was $12.9 \pm 9.5$ years, ranging 2 to 34 years. Twenty-six stones were removed from our 24 patients during the study period. Fifteen stones were 
TABLE I

Level of Spinal Cord Injury

\begin{tabular}{cc}
\hline Level of Injury & Number of Patients \\
\hline $\mathrm{C}_{4}$ & $\mathrm{I}$ \\
$\mathrm{C}_{4}-\mathrm{C}_{5}$ & 3 \\
$\mathrm{C}_{5}-\mathrm{C}$ & 4 \\
$\mathrm{C}_{5}-\mathrm{C}_{6}$ & $\mathrm{I}$ \\
$\mathrm{C}_{6}$ & $\mathrm{I}$ \\
$\mathrm{T}_{3}$ & $\mathrm{I}$ \\
$\mathrm{T}_{4}$ & $\mathrm{I}$ \\
$\mathrm{T}_{4}-\mathrm{T}_{5}$ & $\mathrm{I}$ \\
$\mathrm{T}_{5}$ & 2 \\
$\mathrm{~T}_{6}$ & 2 \\
$\mathrm{~T}_{6}-\mathrm{T}_{9}$ & $\mathrm{I}$ \\
$\mathrm{T}_{9}-\mathrm{T}_{10}$ & $\mathrm{I}$ \\
$\mathrm{T}_{11}$ & 3 \\
$\mathrm{~T}_{12}$ & $\mathrm{I}$ \\
$\mathrm{L}_{4}-\mathrm{L}_{5}$ & \\
$T_{0}$ & 25 \\
\hline
\end{tabular}

located in the renal pelvis (Io on the right and five on the left side); Io stones were found in the urinary bladder and one in the ureter. Twenty-five of the 26 stones submitted for analysis contained 90 per cent magnesium ammonium phosphate and Io per cent carbonate apatite. The remaining single stone was composed of 90 per cent calcium oxalate monohydrate and Io per cent magnesium ammonium phosphate. All the observed stones were radio-opaque and 15 of the 26 had staghorn configuration.

Urinary tract infection was noted in all patients. The infecting organisms consisted of proteus mirabilis in 13, proteus morgagnii in four, proteus stuarti in two, pseudomonas aeruginosa in $13, E$. coli in two and providentia in two instances. Infection with multiple organisms was frequently encountered.

Urine $\mathrm{pH}$ measured by $\mathrm{pH}$-meter on fresh samples was $8.5 \pm 0.7$ units ranging 7.5 to 9.6 units. The indications for surgical intervention included intractable urinary tract infection, deteriorating renal function, pain, haematuria and obstruction. The surgical approach consisted of transurethral lithotomy in four, suprapubic cystotomy in six and pyelolithotomy in 14 instances.

The mean serum creatinine and BUN concentrations were $2 \cdot 0 \pm \mathrm{I} \cdot 3$ and $28 \cdot 0 \pm$ $\mathrm{I} 5.0 \mathrm{mg} / \mathrm{dl}$ prior to surgery and $\mathrm{I} \cdot 6 \pm \mathrm{I} \cdot 2$ and $22 \cdot 0 \pm \mathrm{I} 3 \cdot 0 \mathrm{mg} / \mathrm{dl} \mathrm{I}-4$ weeks following the operation. $(P<0.05$ and $P<0.001)$.

\section{Discussion}

High incidence of urolithiasis in patients with spinal cord injury has long been recognised. Due to better understanding and management of urinary tract infection and urinary drainage the incidence of urolithiasis has declined considerably among the SCI patients during the past decade. The issue, nevertheless, has not been completely resolved and continues to be a problem. Severalfactors are thought to be operative in promoting stone formation in this setting. Increased bone 
resorption due to immobilisation leads to hypercalciuria which in turn predisposes to the formation of calcium-containing stones. Neuropathic bladder dysfunction, commonly associated with spinal cord injury, leads to urinary stasis and urinary tract infection. Urinary stasis may predispose to stone formation by facilitating crystal growth and aggregation (Pyrah, 1979). One of the major complications of the neuropathic bladder dysfunction, however, is urinary tract infection which is probably the single most important factor in the pathogenesis of urolithiasis in this setting. According to Pearman (I97I) stone formation can be effectively prevented by prompt eradication of urinary tract infection in these patients. Infection may contribute to the development of stones in the urinary tract by several mechanisms:

(a) The tissues injured by the infectious process can be calcified and serve as a station for precipitation of stone constituents.

(b) The inflammatory debris can serve as nidi for formation of various stones.

(c) Infection with urease-producing organisms results in production and release of large amounts of ammonium and marked elevation of urine $\mathrm{pH}$. Since ammonium is one of the constituents of magnesium ammonium phosphate, its increased urinary concentration can promote formation of stones containing this substance. This is further facilitated by the concomitant elevation of urine $\mathrm{pH}$ which is known to promote formation of struvite and calcium phosphate stones. Urinary tract infection was present and urinary $\mathrm{pH}$ was markedly elevated in all of our patients. Providentia and proteus species, bacteria well known to produce urease, were cultured from the urine of 2I patients. Magnesium ammonium phosphate (struvite) was the main ingredient of 25 of the 26 analysed stones. The single remaining stone also contained some magnesium ammonium phosphate although not as its predominant constituent. Our findings relative to the composition of the urinary stones are in general agreement with those of Nordin et al. (I967). In addition to struvite, small amounts of carbonate apatite $\left[\mathrm{Ca}_{10}\left(\mathrm{PO}_{4}\right)_{6} \mathrm{CO}_{3}\right]$ were found to be present in 25 of the 26 tested stones. During urealysis not only are large amounts of ammonia produced but also considerable quantities of $\mathrm{CO}_{2}$ are generated and which are eventually converted to carbonate $\left(\mathrm{HCO}_{3}\right)$ as a result of elevated $\mathrm{pH}$. It is, therefore, not surprising that carbonate apatite is found along with struvite in the resulting stones.

Ten of the twenty-six stones included in this report had been removed from the urinary bladder. With the exception of bladder calculi in children, residing in the endemic areas of the world, infravesical obstruction or foreign body are almost invariably responsible for these calculi (Wright and Howard, I98I). Due to neuropathic dysfunction infravesical obstruction was present in all our patients. Indwelling catheters, inflammatory debris, fragments released from the calculi lodged in the upper urinary tract or detached from the calcific deposit on the indwelling catheters constitute possible sources of foreign body in such patients.

Serum creatinine and blood urea nitrogen concentration fell significantly following removal of the stones in our patients. Urolithiasis therefore appears to be a largely reversible component of renal dysfunction in this setting, and some improvement of renal function may be expected with the removal of the stone.

\section{SUMMARY}

Twenty-six stones were surgically removed from 24 patients with spinal cord injury. Magnesium ammonium phosphate was present in all 26 stones and was the main constituent of the stones in all but one instance. All patients had chronic urinary tract infection and their urine $\mathrm{pH}$ was markedly elevated. Renal function 
improved following surgical removal of the stones as evidenced by a significant fall of serum creatinine and BUN concentrations I-4 weeks after surgery.

\section{ZUSAMMENFASSUNG}

Sechsundzwanzig Nierensteine wurden von 24 patienten operativ entfernt. Phosphat Ammoniakmagnesia wurde in allen 26 Steinen gefunden and war, mit einer Ausnahme, der wichtigste Bestandteil aller Steine. Alle Patienten hatten chronische Infectionen der Harnwege und erhöhte $\mathrm{pH}$ Werte. Die operative Entfernung der Nierensteine führte zur Besserung der Nierenfunktion und niedrigeren Kreatinin- und Rest-N-Werten, I-4 Wochen nach der Operation.

\section{RÉSUMÉ}

Vingt-quatre patients avec des blessures de la colonne vertébrale ont subi des operations pour des calculs rénaux. Parmi les vingt-six calculs étudies, tous contiennent du phosphate ammonique de manganèse et celà représente la partie majeure de tous, sauf un des calculs. Tous ces patients avaient des infections chroniques des voies urinaires et leur $\mathrm{pH}$ urinaire était élevé. Leur fonction rénale s'est ameliorée suivant l'élimination chirurgicale des calculs, manifesté par une baisse significative de créatinine et de $\mathrm{N}$ dans le serum, $\mathrm{I}-4$ semaines après l'operation.

\section{REFERENCES}

BURR, R. G. (1972). Urinary calcium, magnesium, crystals, and stones in paraplegia. Paraplegia, I0, 56-63.

DAMANSKI, M. (1963). Stone disease in paraplegia. Paraplegia, 1, I49-156.

FREEMAN, L. W. (1949). The metabolism of calcium in patients with spinal cord injuries. Ann. Surg., 129, I77.

Nordin, B. E. C. \& Hodgkinson, A. (1967). Urolithiasis. Adv. Int. Med., 131, I55.

PEARMAN, J. W. (197I). Prevention of urinary tract infection following spinal cord injury. Paraplegia, 9, 95-I04.

Pyrah, L. N. (I979). Renal calculus, pages I27-I48, Springer-Verlag (publisher).

WRIGHT, F. S. \& HowARDS, S. S. (I98I). Obstructive injury, page 2022. In The Kidney, Brenner and Rector (editors), Saunders (publisher). 